\title{
Additional information on Mycocitrus aurantium (Bionectriaceae, Hypocreales), an unusual bamboo-inhabiting fungus found in South America
}

\author{
Clarice Loguercio-Leite ${ }^{1}$ \\ Larissa Trierveiler-Pereira ${ }^{1}$ \\ Alice Gerlach ${ }^{1}$ \\ Marisa de Campos-Santana ${ }^{1}$ \\ Cecilia Cristina Carmarán ${ }^{2,3}$ \\ Andrea Irene Romero ${ }^{2,3 *}$ \\ ${ }^{1}$ Laboratório de Micologia, Departamento de Botânica, Centro de Ciências Biológicas \\ Universidade Federal de Santa Catarina \\ Campus Universitário, Florianópolis, CEP 88040-900 - SC, Brasil \\ ${ }^{2}$ Departamento de Biodiversidad y Biología Experimental, Facultad de Ciencias Exactas y Naturales \\ Universidad de Buenos Aires, Buenos Aires, Argentina \\ ${ }^{2}$ CONICET - Universidad de Buenos Aires, Instituto de Micología y Botánica (InMiBo) \\ Buenos Aires, Argentina \\ * Autor para correspondência \\ romero@bg.fcan.uba.ar
}

Submetido em 26/06/ 2017

Aceito para publicação em 07/02/2018

\section{Resumo}

Informações adicionais sobre Mycocitrus aurantium (Bionectriaceae, Hypocreales), um fungo incomum encontrado na América do Sul. Mycocitrus Möller corresponde a um gênero tropical que contém duas espécies que formam grandes estromas em colmos de bambu. Durante um levantamento de macrofungos no estado de Santa Catarina foram coletados quatro espécimes de Mycocitrus aurantium Möller, uma espécie considerada rara por ter sido pouco citada na literatura. Os objetivos desse trabalho foram contribuir para o conhecimento sobre a morfologia da espécie, comunicar pela primeira vez a obtenção de cultura da espécie e discutir seu posicionamento filogenético com base em dados moleculares. Estudos morfológicos e filogenéticos foram conduzidos a partir de espécimes frescos e culturas. A filogenia apresentada foi construída com base na sequência do espaçador interno transcrito do DNA ribossomal (ITS). Atualmente, o gênero Mycocitrus é aceito na família Bionectriaceae (Hypocreales); entretanto, este posicionamento não se sustenta quando apenas os caracteres morfológicos são levados em consideração.

Palavras-chave: Ascomycetes; Fungos neotropicais; ITS; Taxonomia de fungos 


\section{Abstract}

Mycocitrus Möller is a tropical genus that comprises two species, which form large orange stromata on bamboo culms. An ongoing survey of macrofungi in Santa Catarina State, Brazil, has produced four collections of Mycocitrus aurantium Möller. This species is considered rare and few records of it are found in the literature. The goals of this work are to improve what is known about the morphology, report the first culture and discuss the phylogenetic position of $M$. aurantium. Morphological and phylogenetic studies were carried out using fresh specimens and cultures. A phylogeny was constructed based on sequences of the nuclear ribosomal internal transcribed spacer. Currently, Mycocitrus is placed in the Bionectriaceae (Hypocreales); however, its placement at the family level is unclear when considering morphological characters alone.

Key words: Ascomycetes; Fungal taxonomy; ITS; Neotropical fungi

\section{Introduction}

Mycocitrus Möller was first described when it was found growing on culms of living bamboo (Guadua Kunth) and on Microstachys A. Juss. (Euphorbiaceae) in the city of Blumenau, Santa Catarina, in southern Brazil (MÖLLER, 1901).

Mycocitrus aurantium Möller, the type species, is characterized by its large fleshy orange stromata that clasp and surround bamboo culms, with perithecial ascomata partially to fully immersed in the upper region of the stromata. Specimens of $M$. aurantium reported by Rick (1907) were collected on a different bamboo genus (Arundinaria Michx.) in a different region of southern Brazil (the city of São Leopoldo, in the state of Rio Grande do Sul). Rick's collections are kept at PACA, $\mathrm{BPI}$ and $\mathrm{FH}$.

According to Molfino (1930), M. aurantium has been reported for Argentina, where it was growing on Chusquea ramosissima Lindm. in Puerto Delicia, along the shores of the Parana River in Misiones Province. He also mentioned that this species was found in Paraguay; however, there is no herbarium voucher for this report.

Later, a second species, M. phyllostachydis (Syd. \& P. Syd.) Yoshim. Doi (三Ustilaginoidea phyllostachydis Syd. \& P. Syd.), was collected in Japan on Phyllostachys Siebold \& Zucc. and added to the genus (DOI, 1967).

Mycocitrus is undoubtedly a member of the Hypocreales. Möller (1901) placed the genus in “Hypocreaceen, Didymosporae.” Lloyd (1916) agreed with Möller's proposal and stated: "the ascospores and perithecia from the specimen described by
Möller were very similar to those of Hypocrea Fr. and in fact Mycocitrus might be classified as a large Hypocrea." Afterwards, Doi (1967) associated another species of the genus, M. phyllostachydis, with the Hypocreaceae De Not. Rogerson (1970) followed the same placement in this family. However, Rossman et al. (1999) proposed a new family, Bionectriaceae Samuels \& Rossman, which included Mycocitrus. At this time, they designated an epitype for M. aurantium, believing the type was destroyed, but later Rossman (personal communication) found a piece of the type at the herbarium S. Maharachchikumbura et al. (2015) followed Rossman's proposal and placed the species in Bionectriaceae.

Taking into account the scanty number of records and information about this species, the goal of this work is to improve what is known about the species by providing new records, an anamorph description, ITS sequences and SEM details of ascospore ornamentation.

\section{Materials and Methods}

\section{Collection sites and morphology}

During field trips to survey macrofungi in the state of Santa Catarina, southern Brazil, stromata of $M$. aurantium were collected on bamboo culms. Observations, digital images, drawings (with the aid of a camera lucida), and measurements of ascomata, asci and ascospores were made from material mounted in distilled water, $5 \% \mathrm{KOH}$ and phloxine using a Zeiss Axioskop microscope. To identify the species, Möller 
(1901) and Rossman et al. (1999) were consulted. Colors were coded according to Kornerup and Wascher (1978). Voucher material is deposited at FLOR and BAFC (HOLMGREN et al., 1990).

Scanning electron microscopy (SEM) studies were conducted at the Centro de Microscopia, CCB/UFSC, Florianópolis, Brazil. Sections were removed from dried ascomata and dusted onto specimen holders that had double-sided carbon adhesive tape, which were then coated with up to 20 nanometres of gold using an ion sputter coater.

An axenic culture was obtained from internal tissue of the stroma and ascospores of the collection BAFC 51760. A strain was transferred to MEA (KIRK et al., 2008) agar plates and incubated at $25^{\circ} \mathrm{C}$ in the dark. The strain is stored in the BAFC culture collection (BAFC cult. 3843).

\section{Phylogenetic analyses}

To perform the phylogenetic analyses a total of 40 sequences were used in the molecular analyses (38 from GenBank database), including 2 sequences obtained from stroma BAFC 51693 and strain BAFC cult. 3843 (Table 1). Previously, an NCBI BLAST (National Center for Biotechnology Information) search was performed to look for similar sequences. The culture was grown on $0.1 \%$ MEA (w/v) and was incubated at $25^{\circ} \mathrm{C}$ for 21 $\mathrm{d}$ in light/dark. Samples from stromata were frozen at $-80^{\circ} \mathrm{C}$ for one week before extraction.

DNA was extracted from hyphae using an UltraCleanTM Microbial DNA Isolation Kit (MO BIO Laboratories inc., Solana Beach, USA) according to the instructions of the manufacturer. The ITS region of the isolates was amplified using universal primers ITS1 and ITS4 (WHITE et al., 1990). In some cases, the best amplification results were achieved by adding $6 \%$ bovine serum albumin (BSA, Promega Corp.) to the PCR reaction mix. PCR products were purified using a QIAGEN Gel Extraction Kit (QIAGEN Inc.). Both strands of each fragment were sequenced by the Macrogen Service Center. Eutypa leptoplaca (Mont.) Rappaz and Xylaria curta Fr. were chosen as outgroups.

For static homology analyses, the BioEdit sequence alignment editor, version 7.0.5.3 (HALL, 1999), was used to manipulate the sequences. The alignments were deposited in TreeBASE (Submission ID S21609). Two analyses were performed: Bayesian inference and maximum parsimony. Bayesian inference was calculated with MrBayes v. 3.1.2 with a general

TABLE 1: Taxa used in the phylogenetic analysis and the GenBank accession number of the DNA sequences (ITS). Taxon names are according to GenBank record.

\begin{tabular}{lc}
\hline \multicolumn{1}{c}{ Taxon } & Accession number \\
\hline Acremonium persicinum (Nicot) W. Gams & FN706554 \\
Acremonium rutilum W. Gams & AB540580 \\
Ascopolyporus philodendrus J.F. Bisch. & AY886545 \\
Ascopolyporus polychrous Möller & DQ118737 \\
Aschersonia placenta Berk. & JN049842 \\
Beauveria caledonica Bissett \& Widden & HQ880820 \\
Bionectria ochroleuca (Schwein.) Schroers \& Samuels 1 & GU256766 \\
Bionectria ochroleuca (Schwein.) Schroers \& Samuels 2 & GQ302681 \\
Bionectria ochroleuca (Schwein.) Schroers \& Samuels 3 & FJ478131 \\
Bionectria pityrodes Schroers & AY254158 \\
Bionectria ralfsii (Berk. \& Broome) Schroers \& Samuels & FJ025191 \\
Claviceps fusiformis Loveless & DQ522539 \\
Cosmospora coccinea Rabenh. & FJ474072 \\
Cosmospora cupularis J. Luo \& W.Y. Zhuang & EF121864 \\
Cosmospora episphaeria (Tode) Rossman \& Samuels & FJ474073 \\
Cosmospora gigas J. Luo \& W.Y. Zhuang & EF121863
\end{tabular}


Hydropisphaera bambusicola Lechat

GU059594

Hydropisphaera erubescens (Roberge ex Desm.) Rossman \& Samuels

AF422977

Hydropisphaera fungicola Rossman, D.F. Farr \& G. Newc.

EU344903

Hypocrea rufa (Pers.) Fr.

DQ838534

Hypocreopsis amplectens T.W.May \& P.R.Johnst. 1

EU073199

Hypocreopsis amplectens T.W. May \& P.R. Johnst. 2

EU073198

Hypomyces chrysospermus Tul. \& C. Tul.

FJ810134

Hypomyces subiculosus (Berk. \& M.A. Curtis) Höhn.

EU280093

Isaria farinosa (Holmsk.) Fr.

FJ820805

Metacordyceps chlamydosporia (H.C. Evans) G.H. Sung et al.

JN049821

Lasionectria mantuana (Sacc.) Cooke

HM484858

Mycocitrus aurantium Möller BAFC 51693

MG022158

Mycocitrus aurantium Möller BAFC cult. 3843

MG022161

Nectria cinnabarina (Tode) Fr. 1

GU062225

Nectria cinnabarina (Tode) Fr. 2

AF163025

Rotiferophthora angustispora (G.L. Barron) G.L. Barron

AJ292412

Shimizuomyces paradoxus Kobayasi

JN049847

Sphaerostilbella aureonitens (Tul. \& C. Tul.) Seifert et al.

FJ442633

Sphaerostilbella novae-zelandiae Seifert et al.

EF029199

Torrubiella confragosa Mains

AF339604

Torrubiella ratticaudata Humber \& Rombach

DQ522562

Verticillium antillanum R.F. Castañeda \& G.R.W. Arnold

AJ292392

time reversible (GTR) model of DNA substitution and a gamma distribution rate variation across sites (HUELSENBECK; RONQUIST, 2001). Two Markov chains were run from random starting trees for 2 million generations and sampled every 100 generations. The first 5 thousand generations were discarded as burn-in.

A parsimony analysis of the sequence data was performed using NONA version 2.0 (GOLOBOFF, 1997 ) with all characters equally weighted and gaps scored as missing data. The analysis was performed with 2000 replications; costs of 15 for gap opening and 6 for gap extensions were assigned. To determine the support for each clade, a bootstrap analysis was performed with 2000 replications.

\section{Results}

\section{Taxonomy}

Mycocitrus aurantium Möller, Bot. Mitth. Trop. 9: 397 (1901) (Figures 1 and 2)

Stromata globose, $4-9 \times 4-10 \mathrm{~cm}$ diam, light orange to orange (KW 6A5, 5A7), not changing in color in $\mathrm{KOH}$ or lactic acid, centrum of Nectria-type, internal hyphal tissue white, clasping and surrounding the bamboo stem. Ascomata perithecial, partially to fully immersed at the surface, apices barely visible, densely gregarious, arranged in a single layer, orange-yellow to orange (KW4B8, 5A7). Asci cylindrical with simple apex, eight-spored, irregularly biseriate, 44-60(65) $\times$ (3) 4.5-5 $\mu \mathrm{m}$. Ascospores ellipsoid, 1-septate, hyaline, verrucose, (6)9-10 × 3-4 $\mu \mathrm{m}$.

Colony growth on ME slow (1 cm in 10 days), forming compact white mycelia masses, with concentric zones, reversed agar ochraceous. Hyphae covered with amorphous material. Condiogenous cells enteroblastic, monophialidic, integrated, terminal, simple, subulate towards the apex, hyaline, ornamented wall produced on mycelia strands, 10$25 \times 2-3 \mu \mathrm{m}$, up to $50 \mu \mathrm{m}$ long, $1.5-2 \mu \mathrm{m}$ at the apex. Conidia 0 -sepatate, hyaline, smooth, cylindrical, slightly truncate at the base, aggregated into a slime drop, 7-12 (14) $\times 3-4 \mu \mathrm{m}$, biguttulate; germinating through 2-3 germ tubes. 
FIGURE 1: Mycocitrus aurantium. a-c. Macrophotographs of stromata clasping and surrounding the bamboo stem (a. FLOR 32414; b. front, c. back FLOR 31907); d-e. Holotype. f. Culture on MEA, BAFC cult 3883. (scale bars = a. 2 cm; b-c. 3 cm). Photograph 1 a by Renato Rizzaro.
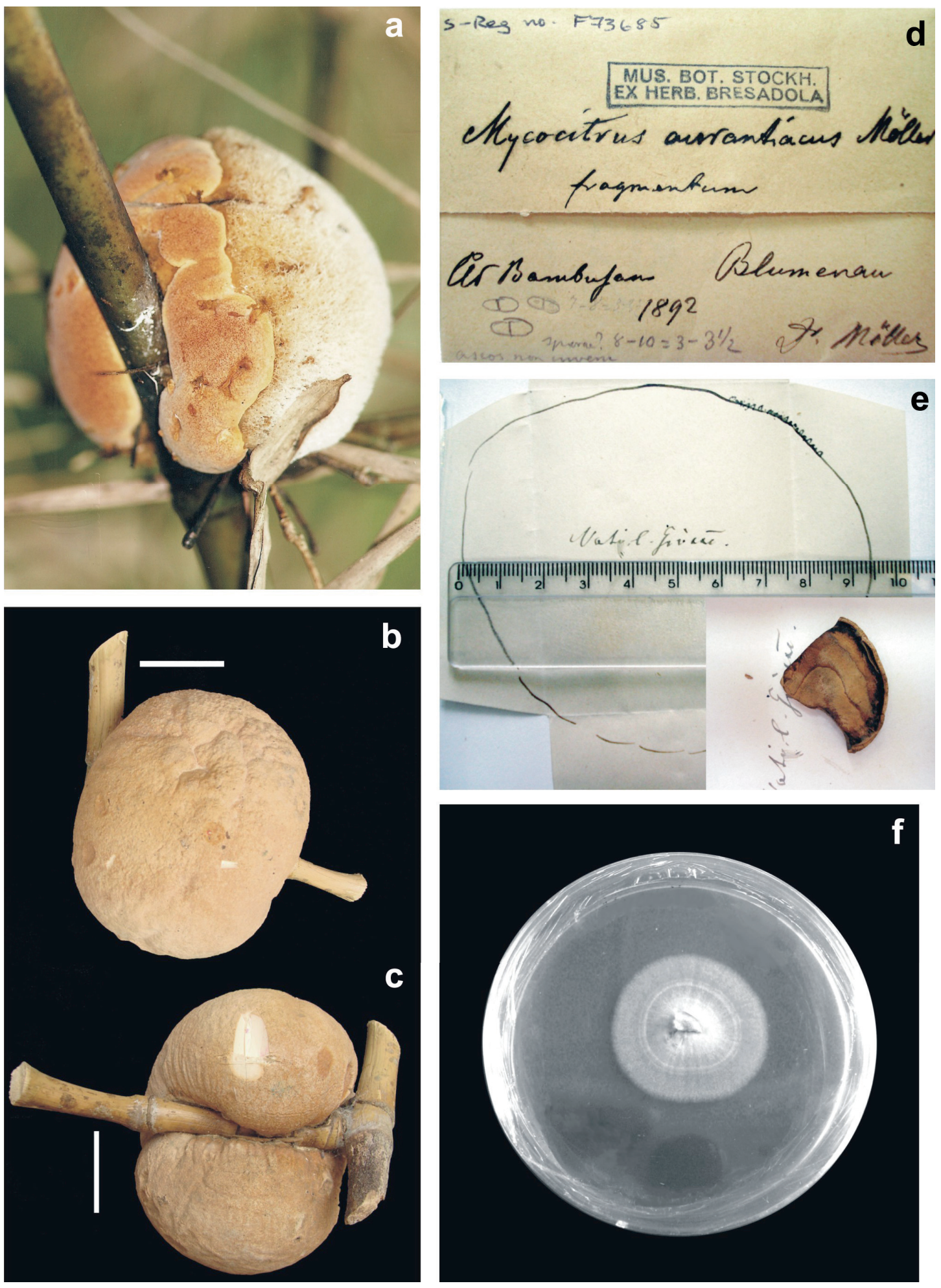
FIGURE 2: Mycocitrus aurantium. a-d. Teleomorph. a. Group of asci; b. Ascospores (a,b FLOR 32414); c. Ascospore (BAFC 51694); d. Ascospore as seen by SEM (FLOR 32414). e-i Anamorph (BAFC cult. 3883). e. Conidiogenous cell and conidia; f. Conidia; g-i Conidia with 1, 2 and 3 germ tubes, respectively. Scale bars: a. $20 \mu \mathrm{m}$; b,e-i. $10 \mu \mathrm{m}$; c,d. $2 \mu \mathrm{m}$.

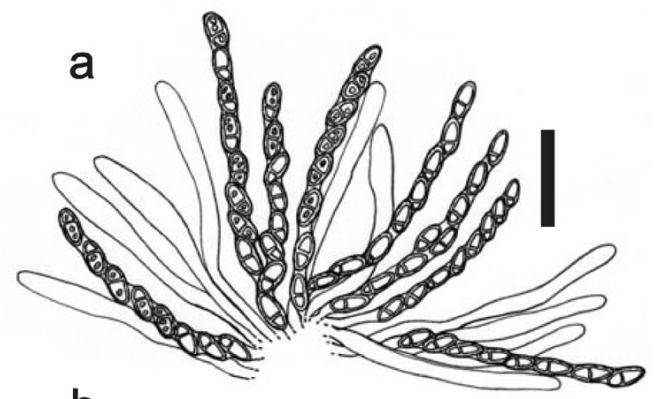

b
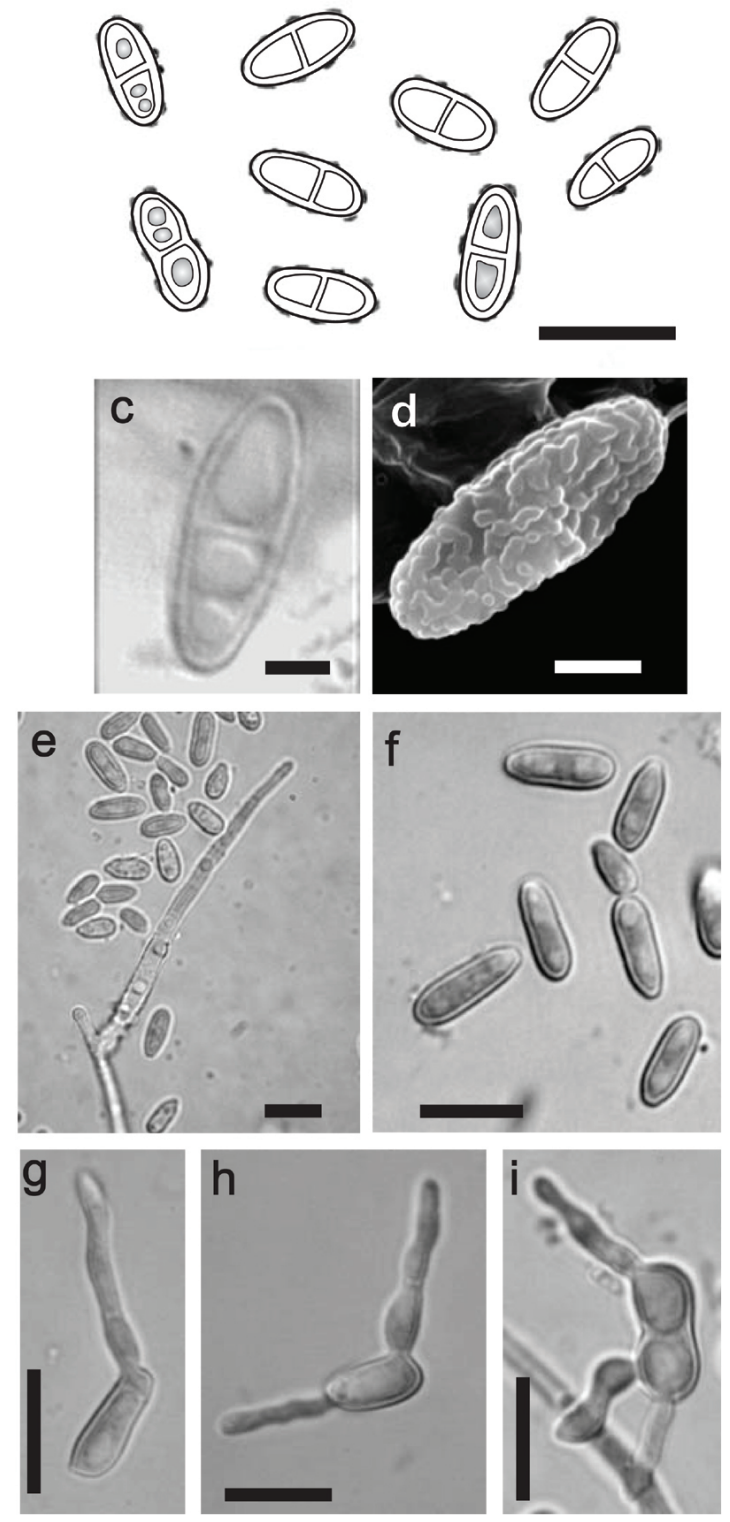

Specimens examined - Brazil, State of Santa Catarina, Mondaí, Linha Uruguai, 2706'16”S5324'07'W, 27 Dec 2006, Campos-Santana \& Santana (FLOR 31907, BAFC 51693); Alfredo Wagner, Reserva Rio das Furnas, 2740'45"S-49¹0'38.4”W, 01 Sep 2007, Gerlach \& Giovanka (FLOR 32414, BAFC 51694); ibid., Gerlach \& Giovanka, 03 Nov 2009 (BAFC 51760, BAFC Cult 3843); Ilhota, Morro do Baú, 265'59''S-48 49'38'W, on Merostachys sp., 19 Nov 2008, Gerlach 229 (FLOR 32413).

Additional specimens examined - Brazil, State of Santa Catarina, Blumenau, on bambusea, 1892, A. Möller (F73685 at S, holotype!); State of Rio Grande do Sul, São Leopoldo, on living bambusea, 1930, J. Rick (SI 22131).

Known distribution - Brazil and Argentina. Molfino (1930) mentioned Paraguay but did not provide collection data.

Comments - Based on morphology, the four recent collections were easily identified as M. aurantium, and no major differences were found when comparing these collections to the holotype and Rick's collection. Mycocitrus phyllostachydis differs from M. aurantium because of its smaller stromata and different ascospore size and ornamentation (ROSSMAN et al., 1999). The axenic culture of $M$. aurantium, deposited in the BAFC culture collection, constitutes the first isolate registered in a culture collection for this species. There is no information about the location of the cultures described by Möller.

Mycocitrus aurantium is easily identified in the field, usually found on bamboo and forms large, orange stromata that sometimes resemble an orange. One of the collected stroma had a few animal bite marks, but it was not severely damaged. It's interesting to mention that this species might be a fungal food source for small monkeys (Callithrix flaviceps) of the New World (HILÁRIO; FERRARI, 2010), like other members of Clavicipitaceae (TRIERVEILER-PEREIRA et al., 2016).

As a curiosity, Molfino (1930) received specimens from a farmer in Misiones (Argentina) and commented that farmers' wives used to gather this fungus to use it as a menstruation regulator. It would be interesting 
to investigate this subject to find out what kinds of metabolites are present in the stroma and to test if they are similar to those produced by members of Clavicipitaceae that are pharmacologically active (BENNETT; BENTLEY, 1999).

\section{Molecular analysis}

With respect to the NCBI BLAST search, the obtained alignments showed low percentages of "query coverage" and "max ident" values. Only one tree was obtained from the maximum parsimony analysis, which had 996 steps, a CI of 0.54, and RI of 0.65 (Figure 3). A similar topology was recovered from Bayesian inference.

In both analyses, the position of Mycocitrus in relation to other taxa appears as a separate clade, clustered with Bionectriaceae, Hypocreaceae and Nectriaceae, with Clavicipitaceae as a sister clade. The bootstrap values and Bayesian posterior probabilities (BPP) are shown in the tree (Figure 3).

FIGURE 3: The most parsimonious tree obtained from nrDNA ITS sequences using maximum parsimony analysis. Clades marked with an asterisk correspond to those not recovered in the Bayesian inference. The bootstrap values are shown above the line (less than $50 \%$ are not shown $)$ and the BPP below the line $(\mathrm{Co}=$ Cordycipitaceae; $\mathrm{Cl}=$ Clavicipitaceae; $\mathrm{M}=$ Mycocitrus-clade; $\mathrm{B}=$ Bionectriaceae; $\mathrm{N}=$ Nectriaceae; $\mathrm{H}=$ Hypocreaceae).

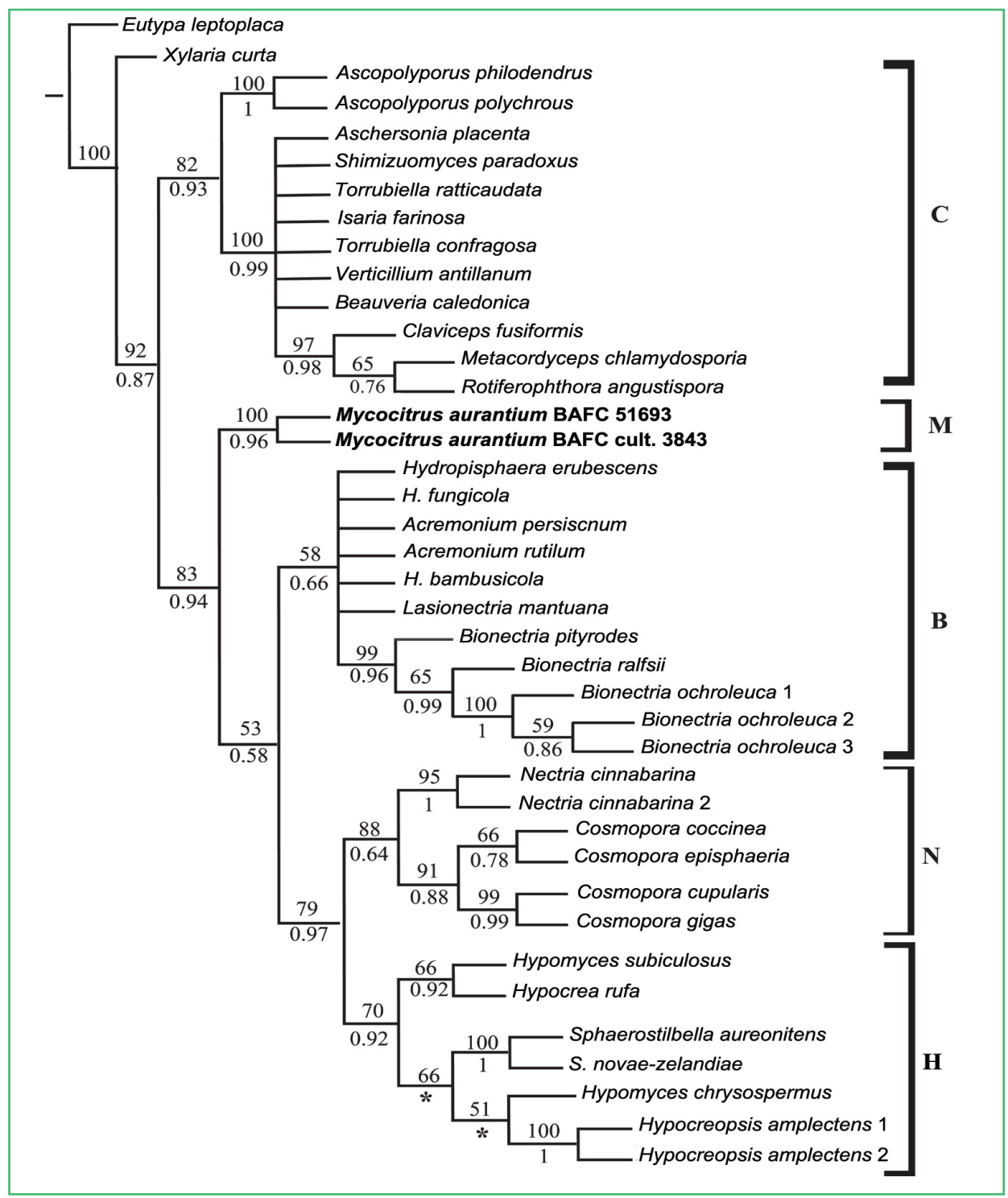




\section{Discussion}

Mycocitrus has a peculiar combination of characters, which includes well develop, large stromata that clasp and surround the bamboo stem, nectriaceous asci, bicellular ascospores and high host specificity. Due to the presence of the stroma, Hara (1957) and Doi (1967) considered it close to Hypocreopsis P. Karst. and Hypocrea.

The proposition by Rossman et al. (1999) to include Mycocitrus in the Bionectriaceae is based on morphology, which could also support placing this genus in its former position in the Hypocreaceae, with which it shares white, pale yellow to orange or brown ascomata and a $\mathrm{KOH}(-)$ reaction. At the same time, microscopically, Mycocitrus could be considered as part of the Nectriaceae, because of its asci and ascospores; however, it differs from this family in the color of the ascomata (generally red to purple) and the $\mathrm{KOH}(+)$ reaction. Consequently, the authors (ROSSMAN et al., 1999) placed Mycocitrus in the Bionectriaceae, apparently because of the ascomata, asci and ascospores that are very similar to many species in this family. There is considerable morphological evidence that Mycocitrus has a unique combination of characters not shared by the traditional families in the Hypocreales; thus, the available information drives us to rethink its placement.

When considering the anamorphic state, the current morphological results agree with the observations made by Doi (1967) and Rossman et al. (1999), bearing in mind the conidial form is Acremonium-like for $M$. aurantium and M. phyllostachydis.

The recovered clades in this study represent the families Bionectriaceae, Nectriaceae, Cordycipitaceae, Clavicipitaceae and Hypocreaceae. This supports the hypothesis of the existence of cryptic lineages within the Hypocrelaes that was suggested by Rossman et al. (2001), Castlebury et al. (2004), and Sung et al. (2007). The topology of our trees suggests that Mycocitrus represents an additional lineage within the order. Molecular data obtained during this study, as well as morphology, showed that Mycocitrus splits from other studied members of Bionectriaceae.
Additional studies should include other molecular markers to test the hypothesis of placing this genus in its own family. Therefore, more robust molecular data are desirable to finally understand the phylogenetic position of Mycocitrus within the Hypocreales.

In addition, with respect to Hypocreopsis, it is worth mentioning that Jonhston et al. (2007) placed H. amplectens T.W.May \& P.R.Johnst among the Hypocreales but with no clear relationship within the order. In our analyses, this genus appears close to genera of the Hypocreaceae, suggesting that this taxon could be placed in this family.

\section{Acknowledgements}

The authors thank Anna-Lena Anderberg from the Department of Cryptogamic Botany, at the Swedish Museum of Natural History, for the loan of the type of $M$. aurantium. The authors are grateful to Renato Rizzaro/Reserva Rio das Furnas for the photograph from the field, and the Laboratório Central de Microscopia Eletrônica at UFSC for the SEM analyses. This study was partially financed by the Conselho Nacional de Desenvolvimento Científico e Tecnológico, Brazil (http://www.cnpq.br), the Universidade Federal de Santa Catarina/Programa AUGM - Escala Docente, 2010/Brazil, and, in Argentina, the Consejo Nacional de Investigaciones Científicas y Técnicas (CONICET), Programación Científica de la Universidad de Buenos Aires y Ciencia y Técnica (UBACYT X122) and Agencia Nacional de Promoción Científica y tecnológica (PICT 2007/01346), PROPLAMEPRHIDEB publication no 187.

\section{References}

BENNETT, J. W.; BENTLEY, R. Pride and prejudice: the story of ergot. Economic Botany, New York, v. 57, p. 463-416, 1999.

CASTLEBURY, L. A.; ROSSMAN, A. Y.; SUNG, G. H.; HYTEN, A. S.; SPATAFORA, J. W. Multigene phylogeny reveals new lineage for Stachybotrys chartarum, the indoor air fungus. Mycological Research, Manchester, v. 108, p. 864-872, 2004.

DOI, Y. A revision of Hypocreales with cultural observations. II. On Mycocitrus phyllostachydis (Syd.) Doi, a perfect state of Cephalosporium. Bulletin of the National Science Museum, Tokyo, v. 10, p. 31-36, 1967. 
GOLOBOFF, P. A. NONA, version 2.0 for Windows. 1997. Available at: <http://www.cladistics.com>. Accessed on: 27 October 2011.

HALL, T. A. BioEdit: a user-friendly biological sequence alignment editor and analysis program for Windows 95/98/NT. Nucleic Acids Symposium Series, Oxford, v. 41, p. 95-98, 1999.

HARA, K. Ascomycetes on Bamboo II. Transactions of the Mycological Society of Japan, Tokyo, v. 1, n. 4, p. 3-7, 1957.

HILÁRIO, R. R.; FERRARI, S. F. Feeding ecology of a group of buffy-headed marmosets (Callithrix flaviceps): fungi as a preferred resource. Amarican Journal of Primatology, New York, v. 72, p. 515-521, 2010.

HOLMGREN, P. K.; HOLMGREN, N. H.; BARNETT, L. C. Index Herbariorum. Part I: The Herbaria of the world. New York: New York Botanical Garden, 1990. 693 p.

HUELSENBECK, J. P.; RONQUIST, F. MrBayes: Bayesian inference of phylogenetic trees. Bioinformatics, Oxford, v. 17, p. 754-755, 2001.

JONHSTON, P. R.; MAT, T. W.; PARK, D.; HORAK, E. Hypocreopsis amplectens sp. nov., a rare fungus from New Zealand and Australia. New Zealand Journal of Botany, Wellington, v. 45, p. 715-719, 2007.

KIRK, P. M.; CANNON, P. F.; MINTER, D. W.; STALPERS, J. A. Dictionary of the Fungi. 10 ed. Oxon: CAB International, 2008. $72 \mathrm{p}$.

KORNERUP, A.; WANSCHER, J. H. Handbook of colour. London: Methuen, 1978. 243 p.

LLOYD, C. G. Mycocitrus aurantium from Pio Buck, Brazil. Mycological Notes of the Lloyd Library and Museum, Cincinnati, v. 41, p. 565-566, 1916.

MAHARACHCHIKUMBURA, S. S. N.; HYDE, K. D.; JONES, E. B. G.; MCKENZIE, E. H. C.; HUANG, S. K.; ABDELWAHAB, M. A.; DARANAGAMA, D. A.; DAYARATHNE, M.; D'SOUZA, M. J.; GOONASEKARA, I. D.; HONGSANAN, S.; JAYAWARDENA, R. S.; KIRK, P. M.; KONTA, S.; LIU, J. K.; LIU, Z. Y.; NORPHANPHOUN, C.; SHENOY, B. D.; XIAO, Y.; BAHKALI, A.H.; KANG, J.; SOMROTHIPOL, S.; SUETRONG, S.; WEN, T.; XU, J. Towards a natural classification and backbone tree for Sordariomycetes. Fungal Diversity, Chiang Mai, v. 72, p. 199-301, 2015.
MOLFINO, J. E. Nota sobre Mycocitrus aurantium Möll. Curiosa especie de ascomiceta de la selva de Misiones. Anales de la Sociedad Científica Argentina, Buenos Aires, v. 109, p. 137-143, 1930.

MÖLLER, A. Phycomyceten und Ascomyceten. Untersuchungen aus Brasilien. Botanische Mittheilungen aus den Tropen, New York, v. 9, p. 1-319, 1901.

RICK, J. Fungi austro-americani Fasc. V. u. VI. Annales Mycologici, Berlin, v. 5, p. 28-31, 1907.

ROGERSON, C. T. The Hypocrealean fungi (Ascomycota, Hypocreales). Mycologia, Stanford, v. 62, n. 5, p. 865-910, 1970.

ROSSMAN, A. Y.; SAMUELS, G. J.; ROFERSON, C. T.; LOWEN, R. Genera of Bionectriaceae, Hypocreaceae and Nectriaceae (Hypocreales, Ascomycetes). Studies in Mycology, Utrecht, v. 42, p. 1-248, 1999.

ROSSMAN, A. Y.; MCKEMY, A. Y.; PARDO-SCHULTHEISS, R. A.; SCHROERS, H. J. Molecular studies of the Bionectriaceae using large subunit rDNA sequences. Mycologia, Stanford, v. 93, p. 100-110, 2001.

SUNG, G. H.; HYWEL-JONES, N. L.; SUNG, J. M.; LUANGSAARD, J. J.; SHRESTHA, B.; SPATAFORA, J. W. Phylogenetic classification of Cordyceps and the clavicipitaceous fungi. Studies in Mycology, Utrecht, v. 57, p. 5-59, 2007.

TRIERVEILER-PEREIRA, L.; SILVA, H. C. S.; FUNEZ, L. A.; BALTAZAR, J. M. Mycophagy by small mammals: new and interesting observations from Brazil. Mycosphere, Chiang Rai, v. 7, n. 3, p. 297-304, 2016.

WHITE, T. J.; BRUNS, T. L.; LEE, S.; TAYLOR, J. W. Amplification and direct sequencing of fungal ribosomal RNA genes for phylogenetics. In: INNIS, M.; GELFAND, D. H.; SNINSKY, J. J.; WHITE, J. T. (Ed.). PCR protocols: a guide to methods and applications. San Diego: Academic Press, 1990, p. 315-322. 